\title{
Playing Kant at the Court of King Arthur
}

Article

Jubb, R. (2015) Playing Kant at the Court of King Arthur.

Political Studies, 63 (4). pp. 919-934. ISSN 0032-3217 doi: https://doi.org/10.1111/1467-9248.12132 Available at https://centaur.reading.ac.uk/43033/

It is advisable to refer to the publisher's version if you intend to cite from the work. See Guidance on citing.

To link to this article DOI: http://dx.doi.org/10.1111/1467-9248.12132

Publisher: Wiley

All outputs in CentAUR are protected by Intellectual Property Rights law, including copyright law. Copyright and IPR is retained by the creators or other copyright holders. Terms and conditions for use of this material are defined in the End User Agreement.

\section{www.reading.ac.uk/centaur}

\section{CentAUR}

Central Archive at the University of Reading

Reading's research outputs online 


\section{Playing Kant at the Court of King}

\section{Arthur1}

There has recently been an increasing focus on the alleged inappropriateness of much of the dominant paradigm of highly idealised theories of abstract virtues like justice in contemporary political philosophy. There, the focus has tended to be on whether such idealised theories provide appropriate concrete guidance about what we should do here and now (Farrelly, 2007; Sen, 2006). Indeed, ideal theory has been defined as theory which does not provide that guidance (Stemplowska, 2008, p. 324). ${ }^{2}$ That debate, however, has obscured another, related but not identical discussion that has also become increasingly important in the past five or so years. What Bernard Williams called realism does not only criticise contemporary egalitarian liberals for failing to draw detailed policy implications from their theories (Williams, 2005a: hereafter RMPT). Realists deny that the ideals articulated by what Williams called political moralists are appropriate because they deny that ideals, at least of that sort, are appropriate in politics at all.

Participants in the more prominent debate over ideal theory have tended to understand this critique as one of the feasibility of liberal egalitarian ideals, given actually existing agents' motivational sets (Stemplowska and Swift, 2012, pp. 379-381; Valentini, 2012, pp. 659-661). ${ }^{3}$ However, the problem is not that we do not know how to realise liberal egalitarian ideals, though we may not. Instead, realists claim that thinking that what we ought to do is realise them is a category mistake, misrecognises the problems political philosophy must respond to. As

\footnotetext{
${ }^{1}$ (acknowledgments)

2 For an alternative definition, and my own contribution to that debate, see Jubb 2012.

${ }^{3}$ Stemplowska and Swift acknowledge, but do not really explore, the 'applied ethics' critique. The only exceptions I am aware of are Sangiovanni 2008 and Gledhill 2012. I take myself to be extending Sangiovanni's discussion, and find Gledhill's use of the ideal theory debate unhelpful for the reasons I outline.
} 
Williams put it, we can imagine ourselves as "Kant at the Court of King Arthur" if we please, but it is not clear what real problem this will help us understand (RMPT, p. 10). Perhaps political moralism does get our moral ideals right, but that is not what we should be doing in politics. Politics is about something else, reflecting not the unforced force of the better argument but a monopoly on organised violence. The ideal theory debate's focus on achieving progress towards our ideals seems different. Whatever else might be said about that issue, it is not the allegation that Rawls and his followers have misunderstood what politics is.

The realist challenge so understood connects with a number of other debates in mainstream Anglo-American political theory. The idea that political theory ought, in some sense, to be political is central especially to Rawls' later work and increasingly important in its interpretation and assessment. Rawls begins Justice as Fairness: A Restatement by asserting that political philosophy has a role "arising from divisive political conflict and the need to settle the problem of order" (Rawls 2001, p. 1: hereafter JaFAR). His further, explicitly Hegelian requirement of reconciliation historicizes meeting this need (JaFAR, p. 3). Even in $A$ Theory of Justice, he argued that utilitarianism fails because it assimilates the problem of the choice of principles for one person to that of the problem of the choice of principles for the many different members of a society with all their conflicting ends (Rawls, 1971, p. 29: hereafter ToJ). Like the realists, Rawls seems to insist that the distinctiveness of the political ought to somehow constrain our theorising about how its institutions should be arranged. This is despite Rawls being one of the main targets of realists (see for example RMPT and Galston, 2010).

In this paper, then, I compare and contrast the way one realist in particular, Bernard Williams, demands that political theory remain political with the way that Rawls does. In doing so, I aim to understand the power of their different accounts as well as discovering where, if at all, they overlap. In particular, I want to suggest that both have underestimated some of the challenges they face. If realists are to dispel the allure of seeing society either as an arena dominated by power or potentially a community transcending conflict, they must say more about the value of 
the political and its distribution. Equally, though, their work should remind Rawlsians of how their theories need to remain situated in the real political dilemmas we actually face, rather than abstract moral questions without purchase on our problems.

In the first section of the paper, I will locate Bernard Williams in the broader realist camp, saying something about why I have chosen him to compare to Rawls. In the second, I draw out the sense in which Rawls' work is political, comparing and contrasting it with Williams'. I then use two examples to investigate these two authors' accounts of what it means to be political. First, I consider what those accounts have been and could be used to say about G. A. Cohen's advocacy of a particular norm of community as part of the appeal of socialism. Second, I look at Rawls' demand that a society governed by his principles of justice be stable for the right reasons. In doing so, I show that both realists and Rawlsians underestimate the difficulty of the task facing them in justifying their preferred account of the political and its autonomy. I also, albeit indirectly, respond to those who deny that political philosophy ought to be in any sense political.

\section{Williams and Realism}

To locate Bernard Williams within realism, we first need an account of what it is to be a realist. Realism's central theme is that political moralism's alleged aspiration to apply moral or ethical principles to politics is a utopian misunderstanding of politics' point and purpose, with all the dangerous consequences that implies. William Galston's four related strands of realist thought elaborate this theme. On his account, realists "take politics seriously as a particular field of human endeavour"; hold "that civil order is the sine qua non for every other political good"; emphasise "the evaluation and comparison of institutions and regime-types, not only principles"; and demand that moralists acknowledge the limits of the motivational power of reason and so develop a "complex moral and political psychology" (Galston, 2010, p. 408). 
This certainly makes sense of the realist idea that the problem with egalitarian liberals like Rawls is the moralistic attitude they adopt towards politics. It explains why realists emphasise the centrality of conflict to politics and so the importance of compromise as opposed to the assumptions of agreement they see in much mainstream contemporary political philosophy, for example (see for example Horton, 2010). Civil order is the precondition of all other political goods - and of many non-political goods too - because without it, conflict will destroy them. Of course, civil order is a matter of degree. At the limit, though, the total absence of civil order is extremely destructive for agents who must share resources of any significance. We disagree about how to use those resources, and not just because of our different moral conceptions. Even if we could agree on a set of moral principles to govern the use of the resources we must share, it is not clear that we could always abide by these principles or that this would resolve the problem, given how limited and different evidence creates difficulties of interpretation. Endemic and unavoidable conflict instead needs to be confronted with an understanding of the motivations that generate it and how it can be governed by partially redirecting, suppressing, and isolating them. Politics is about the coercive provision of order in situations of moral and other conflict, and our theorising about it has to reflect that to have any purchase on it.

This fits with Williams' critique of political moralism. Williams is insistent that the normative standard we apply to politics must be political. The centrepiece of his realist political theory, the Basic Legitimation Demand, is normative, since it tells us which states have authority over their subjects (RMPT, pp. 5-6). Its normative claim, though, "is inherent in there being such a thing as politics" because of its relation to the 'first political question', "the securing of order, protection, safety, trust, and the conditions of cooperation" so central to Hobbes' work (RMPT, p. 5, 3). Answering Hobbes' question requires the exercise of power, but to count as an answer to that question, there has to be something those who offer it can say about taking people from a situation where they lack the benefits of order to one where they do not. Otherwise, the question has not been answered (RMPT, p. 5). Political moralism's failure is a failure to answer 
that question. Anything it produces that we could try and see as an answer is not couched in the right terms, since it understands neither the goods politics produces nor the mechanisms it uses. More, since Williams argues that answers to the Basic Legitimation Demand have to be contextual and, particularly, sensitive to the history of the people they are answers for, political moralism is often misleadingly, if not dangerously, universalist (RMPT, pp. 7-9).

This makes sense in terms of Galston's four strands. The Basic Legitimation Demand can only be understood in light of the insistence on the autonomy of politics and the ever-present first political question of the preservation of order. The requirement that answers to it be contextual, so that they make sense to those they are answers for, is typical of Williams' consistent hostility towards principled, rationalistic moral theorising, whether deontological or consequentialist. His rejection of Kantian theories of practical reason sees them as reducing human agency to a mere rational will and so misunderstanding the importance of being a particular agent with a particular history and set of beliefs and commitments (Williams, 2011, p. 71ff). Equally, the expanded notion of responsibility consequentialists use obliterates the boundaries between what we and others do and so is massively destructive of our sense of self (Williams, 1988). The complexity and diversity of agents inevitably situated in particular contexts, and so of the pointlessness of abstract principles or theories which do not begin from actual human motivations, is a central theme of all Williams' work. He does not just share the realist emphasis on the autonomy of the political then, but also on the need for theorising that is institutionally and psychologically embedded.

Williams is also a good representative of the realist school because he is distinctive in two ways. First, he is one of the few realists not contradictorily hostile to normativity as such. Raymond Geuss is suspicious "about the normative standpoint as a whole", for example (Geuss, 2002, p. 330). If he really means 'the normative standpoint as a whole', then it is hard to understand how there could be any measure of weight to his suspicions or why anyone, including Geuss, should 
rely on argumentation to shape their views at all. In contrast, Williams is quite happy to acknowledge that he is doing normative work. What matters to him, and supposedly distinguishes his work from that of the political moralists, is that that normativity is political.

Second, Williams shares with Rawlsians a broadly social democratic political perspective, limiting their disagreements to the methodological level. It is difficult to imagine the same Williams who found it "a quaint local obsession of Americans that they insist on defending on principle the right to offer any form of odious racist insult or provocation so long as... it can be represented as a form of speech" defending the Amish's alleged right to remove their children from school on the basis of freedom of association like William Galston, for example (Galston, 1995; Williams, 2005b, p. 19). Equally, his involvement in the British Labour Party's Commission on Social Justice in the early 1990s is only comprehensible of someone on and interested in the broad centre left.

The compatibility of Williams' egalitarian liberal and realist commitments has been questioned by Matt Sleat (Sleat, 2010). Williams repeatedly claimed that under conditions of modernity the only available political legitimations were broadly liberal, at least in the North Atlantic democracies (RMPT, pp. 7-9). Sleat argues that this is problematic in two ways for a realist like Williams (Sleat, 2010, p. 498ff). First, Williams interprets modernity in a particular and not necessarily shared way. This is troublesome because, Sleat alleges, it presupposes the kind of consensus that realists criticize political moralists for relying on. If politics is about finding ways to live together in spite of our disagreements, then our disagreements about our historical situation will make it unavailable as a basis of our political order. Second, liberalism cannot rest happy with that account of its foundations. In order for liberals to coherently endorse their political commitments, they have to see those commitments as generated by processes which are amenable to liberal justifications. If we have been made into liberals by non-transparent or 
coercive means, are deluded about the grounds on which liberalism rests, we face a kind of contradiction.

Matt Sleat is surely right that there is disagreement about the character of our historical situation. However, if we look at the societies where Williams claimed only liberalism could be legitimate, he seems to be roughly right. Of course their forms of governance are not completely liberal, but at least for the past fifty years, they have tended to be more or less democratic, to publicly reject the idea of pre-determined roles based on ethnicity, class or gender, and to respect the basic liberal freedoms of association, conscience and speech. Given realism's quasiempirical, interpretive emphasis, it would be odd if Williams' theory did not take that into account. To remain realists, theorists must object to overly moralised political theories which ignore the political conflicts we actually have. Although Sleat is right that there is conflict about the character of modernity, legitimations have been liberal in the way that Williams argued they must. Perhaps he was wrong that this was because of modernity, but some kind of consensus about something must be being drawn on to allow them to function at all. Unless enough people find liberal political orders at least acceptable, they could not have survived.

The second of Sleat's worries is I think more troubling. Williams' problem is that he, along with others, sees transparency as a particularly important value for liberals (Waldron, 1987). A justification of power cannot rest simply on its own exercise because of his 'critical theory principle', "that the acceptance of a justification does not count if the acceptance itself is produced by the coercive power which is supposedly being justified" (RMPT, p. 6). Because liberals tend to read 'produced by' comparatively expansively, this makes the liberalizing effects of roughly liberal political institutions difficult for them to justify. It can be awkward for liberals to acknowledge that a significant part of what makes us liberals is the construction of our subjectivity by liberal social and political institutions because of how important individuality and autonomy are to them. One way of putting this would be to say that liberals can, for good 
reasons, be perhaps too squeamish about taking their own side, even in a knife fight. Williams is aware of this difficulty, and repeatedly states liberalism's need for an error theory which explains, at least in its own terms, why it has not always occupied its current, ideologically dominant position in Western Europe, North America and the white Commonwealth, and why it is not currently accepted elsewhere (RMPT, p. 9).

Yet it seems any realist political theory is likely to be vulnerable to a variant of the same problem. Williams' problem here is that his explanation of the value of escaping the chaos and uncertainty of the absence of political order also pointed to ends beyond that achievement, ends which might threaten it. It is hard to imagine an understanding of the value of stability which does not, on reflection, suggest something more than that, or, alternatively, collapse back into a justification of brute force. Yet the dilemma for a realist political theory is to explain the value of political order while remaining political and able to motivate obedience to that order from something more than fear of its coercive power. Meeting that challenge may require going beyond straightforwardly Hobbesian concerns with order and stability, and drawing on the sort of moral resources realists criticize moralists for relying on.

\section{Rawls and the Political}

At least from Justice as Fairness: Political not Metaphysical onwards, Rawls claimed that his work was distinctively political. Here, I contrast what I take Rawls to mean by that with what realists in general and Bernard Williams in particular have said about the problems that political philosophy has to confront. I draw out the similarities and differences between the two conceptions of properly political political theory and so highlight the problems they both face. Having done so, I will then be in a position, in the last two sections of the paper, to investigate the resources that those two different conceptions give us, and so evaluate them, as well as whether political philosophy should be political at all. 
Political Liberalism deals with the question of "how is a just and free society possible under conditions of deep doctrinal conflict with no prospect of resolution" (Rawls, 2005, p. xxviii: hereafter PL). This is contrasted with views which are instead comprehensive, in the sense that they address a much wider range of questions and so do not concern themselves only with the special case of the basic structure, and use a much wider range of material to do so. This separation of political and comprehensive doctrines does not, Rawls claims, have its origins in philosophy: it is rather the result of a democratic political culture whose development began in the Reformation (PL, p. xxiff). In a way that strikingly mirrors Williams' understanding of our political situation, political liberalism's problems are distinctively modern problems with their roots in the middle of the last millennium. Here and now we need a freestanding political conception which draws on ideas implicit in the public culture to theorise the institutions we must share as citizens. The hope of a thicker, richer justification of our political institutions is one we must give up on.

Obviously, Rawls and Williams respond to that problem in quite different ways. However, it is useful to begin by observing how much their responses resemble each other. We can then see the differences between them as in conversation with each other and raising questions about the two accounts by pointing to their respective strengths and weaknesses. Where, for example, Rawls claims political philosophy needs to be abstract to address the breakdown of "our shared political understandings" (PL, p. 44), Williams doubts that abstraction will help. Even if we could, as we cannot, typically expect abstraction to generate agreement, it tends to erase conflict and so mischaracterise politics. On the one hand, Williams' response to the need for a legitimation of our political order risks leaving itself too little to say to properly motivate political obedience. On the other hand, Rawls' may expect far too much and so nurture impossible hopes and consequent disillusionment. 
This is only one of the important differences between Rawls and Williams. Others include, for example, Rawls' insistence on the primacy of justice contrasted with Williams' demand that we focus on the more minimal requirement of legitimacy, however that is complicated by Rawls' interest in legitimacy and Williams' in social justice. The central difference, though, to which all others can be related, is between the demandingness of the roles they require political philosophy to fulfil. The four requirements Rawls assigns to political philosophy at the beginning of Justice as Fairness: A Restatement involve it resolving questions of political order, like those at stake in disputes over the relative significance of the liberties of the ancients and the moderns; showing us how our status as citizens fits into the broader set of commitments we have and so orienting us in our social world; reconciling us to that social world, bequeathed to us by our history, by allowing us to see it as having a development we can make sense of; and giving us realistic hope that our society is not on a path of inevitable decline but can be, in its own terms, improved (JaFAR, pp. 1-5). Williams does not reject these roles as such, but rather the extent to which abstract philosophy reasoning will fulfil them.

The first of the four roles Rawls gives to political philosophy is, like the other three, phrased more expansively than Williams would have been happy with. Williams thought it ridiculous to attempt to end the dispute over the relative significance of the liberties of the ancients and the moderns through the abstract considerations Rawls' theory brings to bear (Williams, 2001). Not only are those disagreements about our interests as well as our conceptions of ourselves and our relations to each other, our self-understandings are more much the product of history, upbringing and disposition than of rational reflection. Philosophy therefore cannot resolve that disagreement because it is not only a philosophical disagreement. Philosophy has done enough for Rawls though if the disagreement can "be narrowed so that social cooperation on a footing of mutual respect among citizens can still be maintained" (JaFAR, p. 2). The idea of mutual respect's invocation of Kantian ideas about dignity and things beyond price would have still seemed excessive moralism to Williams, but this is at least as much a difference about the tone 
of the response to the requirement as about the requirement itself. The demand is that enough common ground is found to legitimate a political order to those subject to it. Put like that, Williams could hardly have objected to it. The difference is not in the role itself, but in what is conceived of as fulfilling it.

Fulfilling the three remaining roles ensures that the legitimations offered by a political philosophy are ones which makes sense for the people they are legitimations for, and so could hardly have been objected to as such by Williams. Meeting their demands locates those legitimations in a broader set of commitments, hopes and expectations by fitting citizenship into a network of other practices and roles, and into our social world's development, both as a society with a past and as one with a future. Williams was committed to philosophy being richly contextual in this way tout court. Liberalism needs a theory of error to reconcile us to the way our social world developed, for example. Williams claims that without a theory of error, liberalism cannot explain why we should be liberals. We would be alienated from ourselves and our social world in exactly the way that Rawls wants to avoid through reconciliation. Again, the disagreement is not going to be over the demands themselves but over what counts as meeting them.

For Williams, the problem is the way Rawls characterises appropriate responses to his requirements. Although Rawls more than once refers to Isaiah Berlin's claim that there is no social world without loss (PL, p. 57, 197), Williams cannot think that he had adequately absorbed its importance. For Williams, the comparatively unified account of political values Rawls hopes for is impossible because of the extent of conflict between values. Of course Rawls does not want a completely unified account of political values. Even justice has to be endorsed from a number of different standpoints in Rawls' later work. However, Rawls' work unquestionably does seek a greater degree and depth of agreement than Williams'. That is why Rawls turns to abstraction to try and find a way of controlling the disagreement he is well aware 
exists. This only makes sense if you think there are higher-order, more abstract claims which people can agree on and which connect to the first-order questions they are disagreeing over. Because Williams thought that value pluralism was more extensive than Rawls did, he was less sympathetic to abstraction and so all of his theory's sophisticated philosophical apparatus.

\section{Before the End of History}

Understanding the proper content of the disagreement between Rawls and the realists gives us the opportunity to adjudicate it appropriately. Rawls and the realists do not disagree about whether political philosophy ought to be properly political, contextual, and so on, but about how political philosophy ought to be properly political, about the parts of the context we should draw on, and so on. By looking at how appropriate the concrete judgments their theories generate are, we can then evaluate them on the basis of their performance of their role of giving us plausible beliefs about how we ought to act politically. Which deals best with the challenge they both set themselves of legitimating of our political orders to their members? To do this, I draw on two cases. First, I look at Williams' realist response to G. A. Cohen's advocacy of a principle of community as part of the appeal of socialism, contrasting it with Miriam Ronzoni's Rawlsian response. ${ }^{4}$ There, I suggest that Williams' more concrete criticisms are more appropriate, although I also point to some resources Rawlsians could have mobilised instead. Second, I discuss Rawls' idea of stability for the right reasons, and argue that it suggests that a more complete realist political theory cannot skate over our moral disagreements in the way its advocates imply. Here, I use discussions of characters from the HBO series The Wire to argue that Rawls' moral psychology responds to a demand realists have not yet confronted. Legitimating our political orders will mean both abjuring some of the moral claims Rawlsians sometimes make, and expanding those realists are prepared to rely on.

\footnotetext{
${ }^{4}$ Ronzoni has elsewhere defended Rawlsian methodological commitments against Cohen. See Ronzoni and Valentini 2008.
} 
In his posthumously published Why Not Socialism?, G. A. Cohen argues that we lack the social technologies to implement socialism rather than a moral case for it (Cohen, 2009: hereafter WNS). Cohen argues that we ought to endorse socialism because it fulfils two appealing and complementary moral principles. Here, I focus on the second, the principle of community. This principle of "communal reciprocity" demands that "I serve you not because of what I can get in return by doing so but because you need or want my service, and you, for the same reason, serve me" (WNS, p. 39). Unlike market reciprocity, where "I am willing to serve, but only in order to be served", communal reciprocity values being served and serving together (WNS, p. 41). Cohen also advocated much the same principle of community, again contrasted with characteristic market motivation, in a criticism of the British Labour Party's Commission on Social Justice which Bernard Williams had served on (Cohen, 1997).

In both cases, Cohen's principle of community implies a commonality of purpose. I can only be willing to serve someone because they need my service when I think what they are doing is appropriate and does not ask too much of me. Where there is conflict, either of our ends or our interests, Cohen's principle of community must at least have its scope reduced. When we help others in situations where what we want is not already aligned, we do so not because we want them to succeed but for some other reason. Even if this does not mean we must be motivated by the greed and fear Cohen thinks characterise market interactions, it does mean we cannot be serving them simply because they need our service. The relations of mutual respect that Rawls believes his principles of justice would create, for example, are not ones in which we serve others simply because they need our service. They cannot be, because part of the point of that respect is to create the space for us to pursue different conceptions of the good, conceptions which may conflict. Helping anyone who needed our service would make that pursuit impossible. Neither Rawlsians nor realists can think Cohen's advocacy of an expansive principle of community is appropriately political. Its suppression of difference cannot be suitable for 
agents who stand in a political relationship. By looking at Williams' response to Cohen's criticisms as well as Rawlsian response to Why Not Socialism?, we can compare their relative success in repudiating Cohen's suppression of disagreement.

Williams replied to Cohen's criticisms in his Forward to Basics (Williams, 1997: hereafter FtB). There are two interlinked strands to Williams' response to Cohen's invocation of the value of community. First, he attacks the way Cohen draws a supposedly universal norm from a particular historical context without understanding that context, how it sustained that norm, and what has happened to it. Second, and relatedly, he questions whether Cohen's demand that we act only from attractive motives can be political. Williams acknowledges that Cohen's advocacy of a principle of community has roots in the tradition of the Labour Party. An "experience of a strong sense of community combined with class solidarity" and the hope that this could be generalised to all of society "so that there would be a shared sense of fairness, social humiliation would disappear, and selfish motives would be replaced by altruistic ones" motivated many of its achievements and much of its support, particularly in the post-war period (FtB, p. 54). However, that outlook was not only deformed in various ways, but also the product of deprivation, deprivation which was of course partially made good by the changes that outlook brought about through mechanisms like the Labour Party and its support and expansion of the welfare state. It is not just that the Labour Party cannot then draw on that outlook any more, but that given what the outlook was, wanting to makes no sense. Doing so would mean giving up on the liberalization of what was then the past fifty years and returning to a situation that very outlook demanded the removal of.

In his broader second critique, Williams asks whether Cohen really has any understanding of the range of motivations we can call on in political theory at all. Williams points out that Marx, whom Cohen invokes in his criticism, knew that political action could not take place solely or even mainly on the basis of the sorts of 'attractive' motives Cohen's principle of community 
requires. Unless Cohen thinks history has ended, then he had “better accept the Commission's general definition of the problem of social justice, that aspirations for equality and a sense of community must be applied, by defensible political power, to a world which is significantly driven by other sorts of motivations" (FtB, p. 57). Indeed, in failing to see that politics must continue in all of its grubbiness, Cohen is like one of the utopian socialists whom Marxists "tended to despise" because they had not grasped the importance of either "a sound historical analysis" or "a firmly unsentimental picture of what ma[kes] people act" (FtB, p. 57). Cohen's political principles fail tout court, not just for us, because they fail to understand what the political problem is. It may be true that it would be better if we acted from Cohen's highly solidaristic norm of community, but since our and any other political situation is partly constituted by the fact that we do not, offering this as a diagnosis of how we ought to improve that situation cannot be to the point.

Williams' critique can be contrasted with Miriam Ronzoni's attack on Cohen's principle of community in her Life is not a Camping Trip (Ronzoni, 2011: hereafter LINACT). Ronzoni also runs a more specific and a more general critique, neither of which are quite as sharply political as Williams' are. First, she examines whether Cohen's principle of community is appropriate in another context marked, like the camping trip he uses to illustrate and motivate it in Why not Socialism?, by strong affective bonds, the family. Second, she asks whether the ideal of the person it draws on gives up something we should hold dear. In discussing Cohen's principle of community and the family, Ronzoni stresses the way that a camping trip is characterised by both being strictly limited in time and aiming at a particular kind of solidaristic, frugal experience. Like Williams' more specific critique, her worry here is epistemic. She points to the difficulty of transferring a norm from one context to another by observing that even in other small-scale contexts where norms of equality and community are important like the family, the particular egalitarian and communal norms appropriate for a camping trip are inappropriate. We have different purposes, purposes which require a greater degree of independence - in Virginia 
Woolf's phrase, a room of one's own ${ }^{5}$ - as we can see if we imagine having to live our whole lives on a Cohenite camping trip (LINACT, p. 181). Its norms are appropriate for groups who share "a very specific, and significantly thick, conception of the good life" and so that independence does not matter (LINACT, p. 182). Unless we "embrace community as a central and prevailing value in our lives", we should reject them (LINACT, p. 182).

This is an important way in which Ronzoni differs from Williams, who, other than some asides about the moral costs of thick conceptions of the good life, simply denies that Cohen's norm of community could be appropriate, not only for us in our particular historical context but anyone living before the end of political conflict tout court. Ronzoni, in contrast, defends groups where disagreement continues rather than pointing out that assuming away the problem is no kind of solution to it, describing the kinds of concerns Williams refers to as ones of feasibility (LINACT, p. 183). Although she also sees that Cohen is closer to the utopian socialism than Marxism, she wants to dissolve the appeal of utopias rather than observing that they are beyond our reach. The question of whether we should embrace Cohen's norm of community is open for her and so she refers to what we might find "independently valuable about the creative, inventive, multifaceted, and diverse nature of human undertakings" (LINACT, p. 183).

Who, though, would this abstract justification of political relationships be for? This is not an answer to the question of whether we, with all our disagreements and using the means at our disposal, should suppress conflict so as to realise Cohen's principle of community. If it were an answer to that question, the suppression of difference and so the legitimacy of different forms of political coercion would be at least be relevant. Ronzoni ignores those issues though, despite Rawls' use of what he calls 'the fact of oppression' to describe the problem his theory deals with (PL, p. 37). In making the appropriateness of a Cohenite norm of selflessness turn partly on the relative appeal of the competing and similarly unrealizable moral ideals of free-floating, Millian

${ }^{5}$ Ronzoni repeatedly refers to Woolf. See LINACT, p. 178,180, and 181. 
individuality and solidarism so perfect there are no goods we want to know alone, Ronzoni makes the debate one about ultimate ethical ends and so in an important sense, beyond politics, which exists because we cannot resolve those questions.

Ronzoni's decision to present that argument is probably tactical, given that she wants to respond to Cohen. General inferences from individual cases must be made carefully. Still, the view that Cohen's principle of community is problematic because it depends on the wrong kind of abstract moral ideal is in line with the tone of a piece in which coercion is barely mentioned, and then only to be set aside as irrelevant. What is at stake is the attractiveness of a community united by the sorts of solidaristic bonds that are only sustainable when all share the same thick conception of the good. Instead of all that we know of the history of communities governed by such norms, and the hardship and violence needed to sustain them, we get discussions of (ideal) families and the differences between them and camping trips.

Ronzoni may well not have any problem with objecting to Cohen's norm of community more bluntly, but it is indicative of a difference between her and Williams that she does not, one which is to Williams' credit, at least in terms of clarity about what is wrong with Cohen's view. The greater confidence in the possibility of a philosophical resolution of our conflicts of value and interest is a problem for Rawlsians here then. It leaves them seeing their disputes with their opponents in non-political terms they cannot settle and which do not matter for us or any other agents with political problems. Rather than focusing on what might sustain a community united around a norm of almost complete selflessness for creatures like us and how available or desirable those methods might be, Ronzoni's question is put in terms of ultimate moral ends and so beyond the realm of the political.

\section{Putting Your Hand in the Next Guy's Pocket}


However, this search for deeper and more profound sources of agreement can also give Rawlsians resources that realists like Williams lack. In particular, the requirement that a society governed by Rawlsian principles would be stable for the right reasons incorporates an important element of a political justification that realists lack. This requires that the political settlement can be endorsed as treated as binding from within reasonable comprehensive doctrines and not merely because of the risks of destabilising it. Williams, like other realists, has been scathing about its rejection of considerations about the balance of political forces, saying it "suggests a certain distance from the political" since anyone living in a stable order is "already lucky" (RMPT, p. 2; quoted in Galston, 2010, p. 398). However, stability for the right reasons' search for a deeper and more explicitly moralised source of agreement provides a way of understanding complaints that undermine the legitimacy of a political order realists would currently struggle to account for.

In Justice as Fairness: A Restatement and Political Liberalism, Rawls identifies two sets of goods associated with his theory's account of stability for the right reasons (JaFAR, pp. 200-204; PL, pp. 201-206). First, a society which is governed by his two principles of justice will be good for its members in two ways. They will experience the exercise of the two moral powers as good for them, and the public recognition of their status as free and equal gives them the social bases of self-respect. Second, they will see their cooperation to live under the two principles as a shared achievement, much like a successful orchestra performance. What stability for the right reasons does is ensure the congruence of justice and the good (JaFAR, p. 202). This is important even from the most minimal political point of view since, as Samuel Freeman puts it, if a political doctrine is "destructive of what is best in human character", it is unlikely to command peoples' allegiance in the inevitable times of difficulty and so not provide the necessary assurance (Freeman, 2007, p. 149). 
Freeman's discussion shows that the simply political cannot be separated from questions about what is good for those who must live under its arrangements. That an armed peace may be very little peace at all, though, is not the only reason we have for caring about stability for the right reasons. It is not just that without its goods, the goods of basic order may well be threatened and diminished. It is also that, at least in Williams' terms, a justification of the authority of political power is owed to all those whose obedience it wants to claim, a justification which, at least for us, cannot simply be the observation that we are no longer in a Hobbesian state of nature but must make sense in the context of our judgments about what matters to us. The requirement that the political rules we live under do not systematically frustrate our attempts to live the lives we want, at least when we are prepared to allow others the same opportunity reciprocally, ought to be as important to Williams and other realists as to Rawls. A political settlement we cannot live with is hardly one for us. Whatever demands we think of the citizens of North Atlantic democracies as making, they are not the same demands as citizens of failed or failing states, and so more sophisticated resources than those provided by the simple provision of the goods of political order are going to be necessary. North Atlantic democracies do more than not fail, and the extra they do needs to be made sense of. ${ }^{6}$

Rawls' idea of the social bases of self-respect are particularly useful here. These are the features of a social world which give us "self-confidence as a fully cooperating member of society capable of pursuing a worthwhile conception of the good over a complete life" (PL, p. 318). Rawls doubts that without a guarantee of the social bases of self-respect, a political conception can be stable for the right reasons. It is because utilitarianism cannot be publicly affirmed without risking seriously damaging some peoples' sense of their own worth that it would be rejected as a political conception, for example. Realists may scoff at Rawls' excessive moralism here, but we can understand a number of contemporary political challenges in terms of the social bases of self-respect. Not least of these is the disillusionment generated by deindustrialization, a

\footnotetext{
${ }^{6}$ Obviously, different considerations will be relevant in different times and places.
} 
disillusionment particularly vividly illustrated by the fate of the Sobotkas in the second season of the HBO drama, The Wire.

The Wire's unifying focus is the Baltimore Police Department's attempts to deal with the city's drug gangs, but through that lens, it drew a broader picture of what it saw as the moral and social collapse of an exemplar of the post-industrial American inner city, attempting to understand that collapse by looking at the institutions which failed to prevent or facilitated it. The plot of the second season concerned, amongst other things, the stevedores' union being used to bring drugs into the city. The union branch is headed by Frank Sobotka, who orchestrates the collection and handover of the shipping containers drugs and other contraband was smuggled in. His son, Ziggy, and nephew, Nick, also work on the docks. Over the course of the 13 episodes of the season, the Sobotkas' involvement in smuggling and associated crime becomes more and more serious and more and more dangerous, until, in the end, it destroys both Frank and Ziggy.

Frank and Ziggy are both presented, by the end of the season, as tragic figures corrupted and eventually brought down by the limited and compromising resources their situation provides them. The power of that narrative depends on being able to make the moral difficulty of their position come alive for the viewer. Without a sense of the importance of what they are struggling for and the sacrifices they have to make to try to get it, we could not see them as corrupted by those struggles and sacrifices. I think we can helpfully understand a significant part of what they are both so desperately trying to secure as the social bases of self-respect. The importance of that idea for an account of political justification that aims at making sense to those it is a justification for is made clear by the lengths Frank and Ziggy are willing to go to try to secure that sense of their place in the world. The world The Wire depicts is not one which offers Frank or Ziggy Sobotka a robust sense of their own importance in it. Its failure to value what they want to achieve is obvious in its refusal to give them a fair chance to get it. As Rawls puts it when 
discussing how the publicity of his two principles secure the social bases of self-respect, "it is natural to experience a loss of self-esteem, a weakening of our sense of the value of accomplishing our aims, when we must accept a lesser prospect of life for the sake of others" (ToJ, p. 181). Because their world requires them to fight constantly to avoid that loss, any justification of the political authorities that organize it rings hollow for Frank and Ziggy. ${ }^{7}$

Frank Sobotka organises the passage of drugs and other contraband through Baltimore's port to fund a political campaign to renovate and expand the docks and so guarantee the future of the dockworkers and their community. Although it is clear that the stevedores have traditionally engaged in petty criminality to provide an additional income, Frank knows he is doing something more even before the suffocation of trafficked women inside a shipping container which opens the season. He is acting against the norms of his community, norms his compliance with gives a sense of himself and his place in the world, to ensure that the community persists and is able to give others, who rely on him, an uncomplicated sense of their place in it. Ziggy is also haunted by his violation of communal norms, although in his case the violation is public. It is understood that he owes his place in a community where others are losing theirs to his father. Because he has not earned his place, nothing he gets from his work is properly his. The guarantee of his status makes it worthless. Instead, he tries to find a sense of his own significance, that what he does matters, elsewhere and quickly finds he cannot. It is crucial for both him and his father that the community they know flourishes so that they are not alienated by being stripped of the only available basis of their self-respect.

Although there are a number of examples which illustrate Frank and Ziggy's need for that particular social basis of self-respect - Frank's complaint that "we used to make shit in this country" but now "just put our hand in the next guy's pocket" when his lobbyist tells him the FBI

\footnotetext{
${ }^{7}$ Indeed, Frank refuses to cooperate with the police precisely because of the authorities' indifference to the slow death of his community (Dickerson, 2003).
} 
investigation into the union means his campaign to renovate and expand the docks is over, for instance (Dickerson, 2003) - perhaps the best is a conversation Frank and Ziggy have after Ziggy has been beaten up by drug dealers and made a scene in the bar the stevedores all drink in (Shill, 2003). Frank catches Ziggy as he is leaving the bar, dragging him down to the docks to talk some sense into him. Ziggy's drunken reminiscences of family arguments illustrative of the pride once available in manual labour and of moments of communal solidarity provided by strikes and accidents derail him though. Frank gives up trying to set Ziggy onto something like the straight and narrow, and they leave. This only makes sense because Frank knows how destructive losing what Ziggy makes him nostalgic for is. His behaviour is a response to that loss, and comprehensible in its terms. Frank has seriously compromised himself fighting to prevent it getting worse.

Of course, part of what Frank's fight to sustain his community has done is undermine civil peace by making large-scale, profitable criminal drug dealing easier. That is not the only reason political justifications should take not of it though. He and Ziggy are alienated from their political community by difficulty of securing a sense of their place in it, and so it will be very hard to justify its authority over them. Even if Rawls' understanding of stability for the right reasons is too demanding, realists should not rest happy with a modus vivendi's avoidance of brute domination. Legitimacy seems to require a more sympathetic approach to the hopes of the members of a political order, at least here and now. In that sense, stability for the right reasons is an authentically realist requirement and so one that political realists like Bernard Williams should take much more seriously. If we cannot prevent political orders from systematically frustrating their members' hopes, then we need to adapt our attitude towards those like the Sobotkas and, relatedly, the kinds of goods we expect our political settlements to achieve. If their expectations cannot be met, then the political order cannot be justified to them. Their demands are, in Rawls' sense, unreasonable, a failure to respect the free and equal status of their fellow citizens. In Williams' starker terms, they are "anarchists... bandits, or merely enemies" 
(Williams, 2005c, p. 136). Either way, they must be contained, forcefully if necessary, and we can no longer see ourselves as in even a thin kind of community with them, however justified our treatment of them is. ${ }^{8}$

\section{Conclusion}

One of the main targets of the realist critique of political moralism is John Rawls. He and his followers are taken as typical of the dangerous turn away from politics in contemporary political philosophy. I have argued here that this is misplaced and that, in fact, Rawls is a political realist of a sort. Particularly in his later writings, he offers a historicized account which starts from much the same sort of questions as those more conventionally grouped under the realist label do. There are differences between the more straightforward realists and Rawls, differences I have tried to locate in Rawls' more demanding understanding of the role political theory has to fulfil. I have also suggested that this sometimes leads Rawls(ians) to seek to resolve philosophical questions they would be better to leave alone, but that realists ought to look more carefully at Rawls' requirement of stability for the right reasons. That requirement is one way of theorising the demand that political orders do not alienate members who accept that its other members must be similarly accommodated. Realists may not want to adopt Rawls' version of this requirement, but they need to incorporate something analogous into their accounts of legitimacy unless they are to treat many members of political orders as threats to their stability that need to be contained. In making these arguments about the respective strengths and weaknesses of Rawls and Williams, I hope to have defended and illuminated the requirement both endorsed, that political theory be properly political.

\footnotetext{
${ }^{8}$ Matt Sleat has recently claimed that political liberalism has no way of justifying its coercion of nonliberals. See Sleat 2013. This seems to me false, because for political liberals, political power is a threat to freedom and equality which is to be justified in those terms. Non-liberals who reject such a justification still have one available. The problem is instead how to live together despite that.
} 
Cohen, G. (1997) 'Back to Socialist Basics', in J. Franklin (ed.), Equality. London: IPPR, pp. 29-48.

Cohen, G. (2009) Why Not Socialism?. Princeton: Princeton University Press.

Dickerson, E. (2003) Bad Dreams.

Farrelly, C. (2007) 'Justice in Ideal Theory: A Refutation', Political Studies, 55 (4), 844-64.

Freeman, S. (2007) 'Congruence and the Good of Justice', in S. Freeman, Justice and the Social Contract: Essays on Rawlsian Political Philosophy. Oxford: Oxford University Press, pp. 143-72.

Galston, W. (2010) 'Realism in political theory', European Journal of Political Theory, 9 (4), 385-411.

Galston, W. (1995) 'Two Concepts of Liberalism', Ethics, 105 (3), 516-34.

Geuss, R. (2002) 'Liberalism and its Discontents', Political Theory, 30 (3), 320-38.

Gledhill, J. (2012) 'Rawls and Realism', Social Theory and Practice, 38 (1), 55-82.

Horton, J. (2010) 'Liberalism, Moralism, and a Political Theory of Modus Vivendi', European Journal of Political Theory, 9 (4), 431-448.

Jubb, R. (2012), 'Tragedies of Non-Ideal Theory', European Journal of Political Theory, 11 (3), 229-246.

Rawls, J. (1971) A Theory of Justice. Cambridge: Harvard University Press.

Rawls, J. (2001) 'Justice as Fairness: A Restatement', Erin Kelly (ed.). Cambridge: Harvard University Press.

Rawls, J. (2005) Political Liberalism. New York: Columbia University Press.

Ronzoni, M. (2011) 'Life is not a camping trip - on the desirability of Cohenite socialism', Politics, Philosophy \& Economics, 11 (2), 171-85.

Ronzoni, M. and Valentini, L. (2008) 'On the Meta-Ethical Status of Constructivism', Politics, Philosophy \& Economics, 7 (4), 403-22. 
Sangiovanni, A. (2008) 'Normative Political Theory: A Flight from Reality?', in D. Bell (ed.), Political Thought and International Relations: Variations on a Realist Theme.

Oxford: Oxford University Press, 219-39.

Sen, A. (2006) 'What Do We Want from a Theory of Justice?', Journal of Philosophy, CIII (5), 215-38.

Shill, S. (2003) All Prologue

Sleat, M. (2010), 'Bernard Williams and the possibility of a realist political theory', European Journal of Political Theory, 9 (4), 485-503.

Sleat, M. (2013), 'Coercing Non-Liberals: Considerations on a more Realistic Liberalism', European Journal of Political Theory, Vol. 12, No. 4 (2013), pp. 347-367.

Stemplowska, Z. (2008) 'What's Ideal about Ideal Theory', Social Theory and Practice, 34 (3), 319-40.

Stemplowska, Z., and Swift, A. (2012) 'Ideal and Nonideal Theory', in D. Estlund (ed.), Oxford Handbook of Political Philosophy. Oxford: Oxford University Press, pp. 373-392. Valentini, L. (2012) 'Ideal vs. Non-ideal Theory: A Conceptual Map', Philosopher's Compass, 7 (9), 654-664.

Waldron, J. (1987) 'The Theoretical Foundations of Liberalism', Philosophical Quarterly, 37 (147), 127-50.

Williams, B. (1988) Consequentialism and Integrity, in S. Scheffler (ed.) Consequentialism and its Critics. Oxford University Press: Oxford, pp. 20-50. Williams, B. (1997) 'Forward to Basics', in J. Franklin (ed.), Equality. London: IPPR, pp. 49-58.

Williams, B. (2001) 'From Freedom to Liberty: The Construction of a Political Value', Philosophy and Public Affairs, 30 (1), 3-26.

Williams, B. (2002) Truth and Truthfulness. Princeton: Princeton University Press. 
Williams, B. (2005a), 'Realism and Moralism in Political Theory', in B. Williams and G. Hawthorn (eds.), In the Beginning was the Deed: Realism and Moralism in Political Argument. Princeton: Princeton University Press, pp. 1-17. Williams, B (2005b) 'In the Beginning was the Deed', in B. Williams and G. Hawthorn (eds.), In the Beginning was the Deed. Princeton: Princeton University Press, pp. 18-28. Williams, B. (2005c) 'Toleration, A Political or Moral Question, in Bernard Williams and Geoffrey Hawthorn (eds.), In the Beginning was the Deed. Princeton: Princeton University Press, pp. 128-138.

Williams, B. (2011), Ethics and the Limits of Philosophy. London, Routledge. 